DOI: $10.15393 /$ j10.art.2019.4041

УДК $821.161 .1 ; 592$

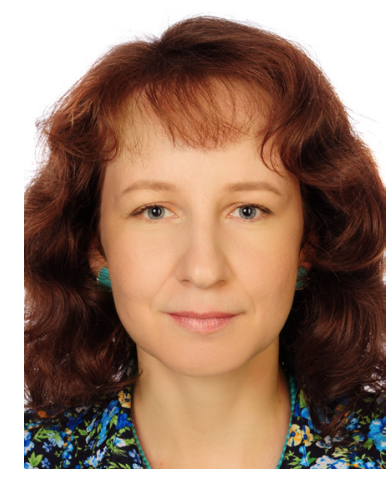

Елена Юрьевна Сафронова

(Барнаул, Российская Федерация)

esafr@mail.ru

\title{
Прототип ученого немца в повести Ф. М. Достоевского «Дядюшкин сон»*
}

Аннотация. В статье предпринимается попытка выявления прототипа образа ученогоэнтомолога в повести Ф. М. Достоевского «Дядюшкин сон». По нашим наблюдениям, им стал Ф. В. Геблер, родоначальник систематической энтомологии на Алтае, автор научных трудов о насекомых «Insecta Sibiriae rariora, descripsit» (= Редкие насекомые Сибири, описание) и «Замечания о насекомых Сибири, в особенности Алтая». Кроме того, в образе энтомолога преломились некоторые черты А. фон Гумбольдта, который посещал Барнаул, и друга писателя П. П. Семенова, который во время экспедиции на Тянь-Шань в 1856-1857 гг. зимовал в Барнауле (столице горного дела на Алтае). Достоевский упоминает в повести «особенный род червячка с рожками». Писатель избирает объектом иронии исследователя очень редкого по численности насекомого Leptura altaica, обитающего в окрестностях Барнаула, пародийно обыгрывает факты и городские предания и создает аллюзии, однозначно отсылающие к Барнаулу.

Ключевые слова: Достоевский, «Дядюшкин сон», образ ученого, Leptura altaica, сибирский текст, Барнаул, Ф. В. Геблер, А. фон Гумбольдт, П. П. Семенов-Тянь-Шанский

Об авторе: Сафронова Елена Юрьевна - кандидат филологических наук, доцент кафедры общей и прикладной филологии, литературы и русского языка, Алтайский государственный университет (656049, Российская Федерация, Барнаул, пр. Ленина, 61)

Дата поступления: 20.04.2019

Дата публикации: 30.06.2019

Для цитирования: Сафронова Е. Ю. Прототип ученого немца в повести Ф. М. Достоевского «Дядюшкин сон» // Неизвестный Достоевский. - 2019. - № 2. - С. 110-129. DOI: $10.15393 /$ j10.art.2019.4041

() Е. Ю. Сафронова, 2019 
B критической и научной литературе повесть «Дядюшкин сон» традиционно оценивалась невысоко, находилась на периферии исследовательского интереса. Несмотря на появление в последнее время работ Р.С. И. Семыкиной (1998), С. А. Кибальника (2013), Б. Н. Тихомирова (2017), В. О. Старыгиной $(2013)^{1}$, произведение остается недостаточно изученным и нуждается в глубоком анализе его творческой истории, художественного мира, образной системы, а также научном комментировании сибирского опыта, преломившегося в этом литературном тексте.

Оказавшись в сибирской ссылке, Ф. М. Достоевский узнал не только скуку и бесцветность Семипалатинска, но и познакомился с Барнаулом культурной столицей региона. В Барнауле писателю понравились не только напоминающая Петербург архитектура, театр, хор, картинная галерея, высокий уровень культурных интересов общества горных офицеров. Важно, что Алтай для Достоевского стал местом близкого знакомства с русской фундаментальной наукой. Речь идет не только о П. П. Семенове (ученомэнциклопедисте, проявившем себя в разных областях естественнонаучного поля: геологии, минералогии, биологии, зоологии и др.), с которым Достоевский был знаком еще по Петербургу, или о начальнике Алтайских горных заводов А. Р. Гернгроссе, успешно внедрявшем новые методы плавки руд и активно совершенствовавшем процесс их добычи, но и о других ученых, оставивших свой след в истории Барнаула. Немаловажно, что знакомство с представителями научной среды косвенно отразилось и в художественных текстах Достоевского: в сибирских произведениях («Дядюшкин сон», «Село Степанчиково») отчетливо проявляется увлечение писателя естественными науками - биологией, минералогией, медициной, астрономией.

В повести «Дядюшкин сон» травестийно обыгрывается увлечение наукой:

«Один немецкий ученый, нарочно приезжавший из Карльсруэ исследовать особенный род червячка с рожками (курсив мой. - E. С.), который водится в нашей губернии, и написавший об этом червячке четыре тома in quarto, так был обворожен приемом и любезностию Марьи Александровны, что до сих пор ведет с ней почтительную и нравственную переписку из самого Карльсруэ»².

Действительно, Алтай был загадкой и точкой притяжения не только для специалистов горного дела и металлургии, но и объектом научного интереса для ученых Германии. В разное время Алтай посетили крупные специалисты в области естественных наук: Иоганн Сиверс, Петер-Симон Паллас, профессор ботаники Карл Ледебур, Александр фон Гумбольдт, его спутники Х. Г. Эренберг и Г. Розе, А. А. Бунге и др. ${ }^{3}$

В процессе анализа оказалось, что исследование «особенного рода червячка с рожками, который водится в нашей губернии», действительно, связано и с Алтаем, и с Германией. 
Обратим внимание на «особенный род червячка с рожками», ставший предметом изучения ученого и пародии писателя. Вполне возможно, Достоевский так обыграл известную ему со слов П. П. Семенова популярную городскую байку. Архивные источники подтверждают, что в 1842 г. енисейский земский управитель представлял образцы червей в Алтайское горное правление, появившихся в Бийской волости на полях в земле глубиною в один вершок и причинявших вред озимым хлебам и травам путем «подъедания» корней растений. В Государственном архиве Алтайского края (ГААК) сохранилась переписка Кабинета с доктором г-ном статским советником и кавалером Ф. В. Геблером о необходимости описания, сохранения и предоставления в «надлежащей укупорке» червей через господина Томского губернатора в Санкт-Петербург министру внутренних дел ${ }^{4}$.

По мнению Григория Яковлевича Стецова ${ }^{5}$, высказанному автору статьи в частной консультации, описываемые в архивных документах вредители озимых культур и трав - это подгрызающие совки. Иногда их даже называют сибирской саранчой - настолько они вредоносны. Рожек у них нет, но задние ножки можно, с некоторой долей фантазии, назвать рожками. С точки зрения современной систематики, озимая совка (Agrotis segetum) относится к семейству чешуекрылых, распространена в Европейской части России до полярного круга, на Северном Кавказе, в Приуралье, на юге Сибири и Дальнего Востока ${ }^{6}$.

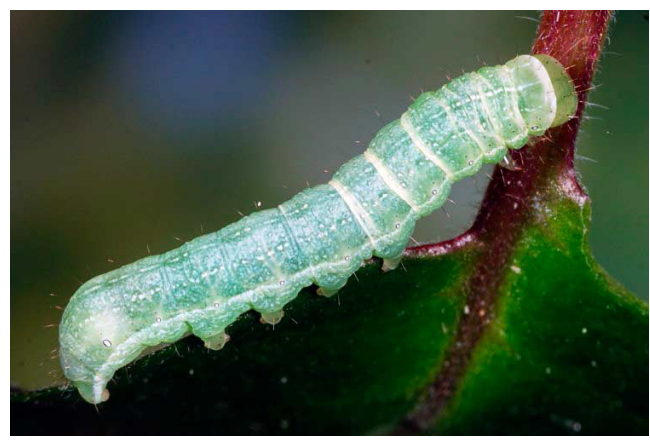

Илл. 1. Гусеница капустной совки ${ }^{7}$

Фридрих Август Геблер (1782-1850) ${ }^{8}$ родился в Саксонии, получил медицинское образование. В 1802 г. блестяще защитил докторскую диссертацию. Поскольку найти постоянную работу на родине он не смог, то в 1809 г. приехал в Петербург. Сдав экзамен в Медико-хирургической академии на подтверждение квалификации доктора медицины и хирургии, Геблер выбрал местом службы Колывано-Воскресенский горный округ на Алтае. С осени 1809 г. Ф. В. Геблер 9 работал врачом Барнаульского горного госпиталя, затем им заведовал, с 1820 г. одновременно с работой в госпитале был назначен инспектором всей медицинской части горного ведомства. 
В журнале «Всеобщие медицинские анналы» за 1812 г. Геблер описывает место своей новой службы. «Императорский российский горный город Барнаул, находится в Томской губернии под 55» 20' северной широты, имеет примерно 6000 жителей. <...> Жилье здесь состоит большей частью из деревянных домов и домишек, комнаты низкие, частью до половины уходят в землю и отапливаются русскими печами. Город расположен при слиянии Барнаулки, небольшой солоноватой речки, которая здесь запружена и образует большой заводской пруд, с Обью. Вода ее для питья непригодна» (цит. по: [Гармс, 2011b: 34]).

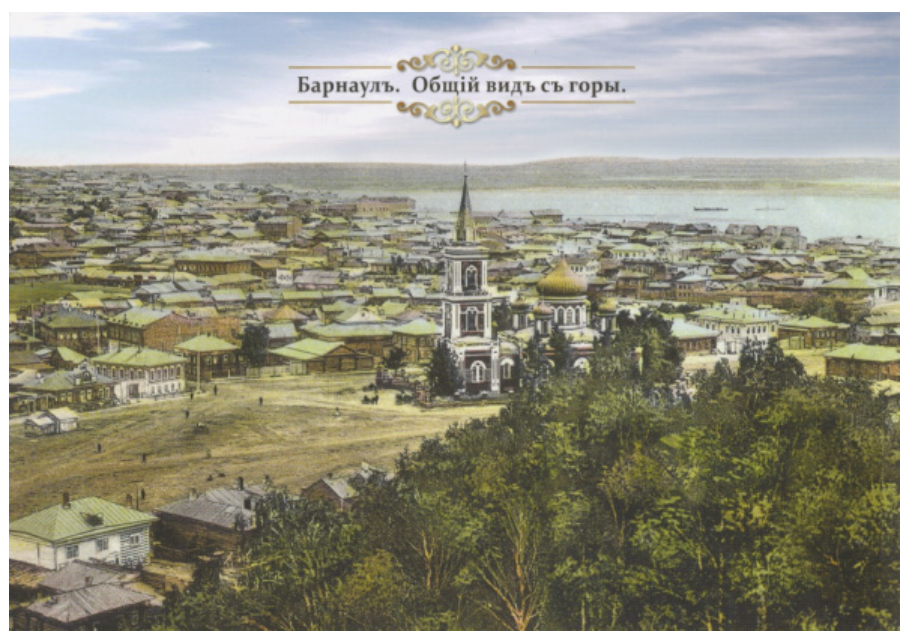

Илл. 2. Барнаул. Общий вид с горы. Конец XIX в.

Фото С. И. Борисова. Открытка, дизайнер А. Л. Кальмуцкий

На Алтае Ф. В. Геблер имел славу «народного доктора» и «доктора для бедных» ${ }^{10}$. Он принадлежал к числу крупнейших ученых-энциклопедистов своего времени, блестяще знал французский язык, публиковал работы на немецком, французском языках и латыни, оставив значительный след в науке сразу в нескольких областях: географии, этнографии, ботанике, зоологии.

Для нас более важно, что Ф. В. Геблер является выдающимся энтомологом Алтая: именно в этом качестве он и заинтересовал Ф. М. Достоевского. В отличие от предшественников: Эрика Густава Лаксмана и Петра Ивановича Шангина, - которые собрали первые энтомологические коллекции Алтая, научная работа Ф. В. Геблера отличалась тщательностью и систематическим характером. Он положил начало научному описанию энтомологической фауны, нашел и описал много новых видов жуков и других насекомых ${ }^{11}$. Ученым была собрана огромная коллекция, содержащая 1401 вид насекомых, впоследствии переданная в организованный при поддержке начальника алтайских заводов П. К. Фролова краеведческий музей. 
Ф. В. Геблер был членом Императорской академии наук, Русского географического общества, Императорского московского общества сельского хозяйства, Императорского московского общества естествоиспытателей, Иенского минералогического общества, Парижского общества Кювье, Пражского общества «Лотос», Общества рейнских натуралистов в Майнце, Энтомологического общества во Франции, Штеттинского энтомологического общества ${ }^{12}$.

Другим возможным прототипом образа немецкого энтомолога мог быть Александр фон Гумбольдт - немецкий ученый-энциклопедист, естествоиспытатель, путешественник, член Берлинской академии наук, почетный член Петербургской академии наук, один из основателей географии как самостоятельной науки. Александр фон Гумбольдт получил известность во время экспедиции в Южную Америку в 1804 г., обнаружившей 60000 растений, их которых 6300 относилось к ранее неизвестным видам ${ }^{13}$. В 1829 г. А. Гумбольдт совместно со своими спутниками и коллегами профессорами Х. Г. Эренбергом и Г. Розе предпринял путешествие по Уралу и Сибири по инициативе Министерства финансов Российской империи ${ }^{14}$. Правительство выбрало для этой экспедиции А. фон Гумбольдта не случайно: немецкий ученый окончил Фрайбергскую горную академию и был крупнейшим географом Европы. Его спутниками были академики РАН Густав Розе (1798-1873) - немецкий минералог и кристаллограф и Х. Г. Эренберг (1795-1876) - естествоиспытатель, путешественник, биолог, профессор медицины в Берлинском университете. А. фон Гумбольдт специально изменил маршрут и пробыл в Барнауле со 2 по 4 августа 1829 г.

Г. Розе описал Барнаул следующим образом: «Окрестности города непривлекательны, однако пребывание в нем может быть очень приятным для местного жителя, поскольку здесь, кроме удобств жизни, можно познакомиться со многими образованными людьми, которые сосредоточены здесь из-за горных заводов Алтая. <...> Особое внимание обратил на себя в Барнауле музей, единственное в Сибири учреждение, которое обязано своим возникновением научному интересу и деятельности $<\ldots .>$ доктора Ф. Геблера - немца, работающего уже долгое время врачом в Барнауле. Он сопровождал нас по музею. Из частных коллекций нас особенно заинтересовали естественно-исторические коллекции доктора Геблера, которые этот замечательный и очень активный коллекционер собрал за время своего пребывания в Сибири. Наиболее полной здесь является энтомологическая коллекция...» (цит. по: [Гармс, 2011b: 51]).

Немецкий ученый дважды встречался с Геблером (см. [Гармс, 2011b: $51-52,85])$. Впечатлениями от общения с ученым мировой величины Ф. Геблер делился в письме к президенту Московского общества испытателей природы профессору Фишеру фон Вальдгейму: «Я имею честь сообщить Вам интересную новость, а именно - господин Гумбольдт <...> неожиданно почтил нас своим посещением <...> Не могу высказать Вам, как я был 
счастлив увидеть этого редкостного, любезного и уважаемого ученого! Он дважды почтил меня своим посещением» (цит. по: [Гармс, 2011b: 54]). Сам А. фон Гумбольдт о Геблере отзывался более сдержанно как об ученом, «большие энтомологические коллекции которого <...> имел возможность видеть в Барнауле» (цит. по: [Гармс, 2011b: 54])

Так, переселившийся на Алтай немецкий ученый Ф. В. Геблер, возможно, ставший прототипом сатирического образа ученого в повести Ф. М. Достоевского, оказался причастным к двум титанам науки: А. фон Гумбольдту и И. В. Гете $\mathrm{e}^{16}$.

Еще один ученый, который также мог стать прототипом ученого-энтомолога, - это Петр Петрович Семенов, посещавший Алтай и непосредственно связанный с автором повести «Дядюшкин сон» дружескими узами. Его характер с долей иронии обрисован и в письме от 9 марта 1857 г. А. Е. Врангелю: «...человек превосходный, умный, нежный и чувствительный, но немного с смешными странностями...» (Д30; $28_{1}: 272$ ). Это комическое описание, возможно, отсылает к некоторым деталям биографии П. П. Семенова: он был магистром ботаники, в 1853-1854 гг. предпринял поездку в Германию для всесторонней научной подготовки, собрал крупнейшую в мире коллекцию насекомых, содержащую свыше 700000 жуков, которая сейчас хранится в Зоологическом музее РАН.

Во время обучения в Берлине, одном из ведущих мировых естественнонаучных центров, П. П. Семенов встретился лично с всемирно известным географом Александром фон Гумбольдтом для обсуждения предполагаемого путешествия в Тянь-Шань [Козлов: 19] ${ }^{17}$. В ходе этой встречи А. фон Гумбольдт мог упомянуть о своем посещении Барнаула и знакомстве с Ф. В. Геблером как крупным энтомологом и основателем краеведческого музея. Как и А. фон Гумбольдт и Ф. В. Геблер, П. П. Семенов принадлежал к числу ученых-энциклопедистов, объединяя в себе геолога, ботаника и зоолога.

В своих научных изысканиях П. П. Семенов, безусловно, учитывал исследования по географии, зоологии и энтомологии своего непосредственного предшественника Ф. В. Геблера, тем более что оба принадлежали к Русскому географическому обществу. В частности, географ и ботаник не чувствовал себя в столице горного дела на Алтае, в которой он провел зиму 1856-1857 гг., как в провинциальной глуши. По его собственному признанию, «зима, проведенная в Барнауле, не казалась мне скучной, день проходил в разборке собранных мной богатых ботанических коллекций, в подробном осмотре и изучении предметов барнаульского музея, в пользовании тамошней библиотекой и в ознакомлении с заводскими работами» ${ }^{18}$. П. П. Семенову была прекрасно известна огромная энтомологическая коллекция Ф. В. Геблера (1401 экземпляр), подаренная собирателем краеведческому музею. В ходе первой экспедиции на Тянь-Шань П. П. Семенов «собрал много насекомых, среди которых также оказалось несколько новых видов и разновидностей» [Козлов: 33]. 
Кроме интереса к науке, была еще одна причина личного характера, которая могла обусловить интерес Достоевского к личности Ф. В. Геблера. Влюбленный в то время в М. Д. Исаеву, писатель вынашивал планы женитьбы и мечтал переселиться в Барнаул. Во время поездок в Кузнецк с целью сватовства и заключения брака он останавливался у П. П. Семенова, квартировавшего в доме купца В. И. Зубова на Большой Олонской улице, 39, у Сенной площади.

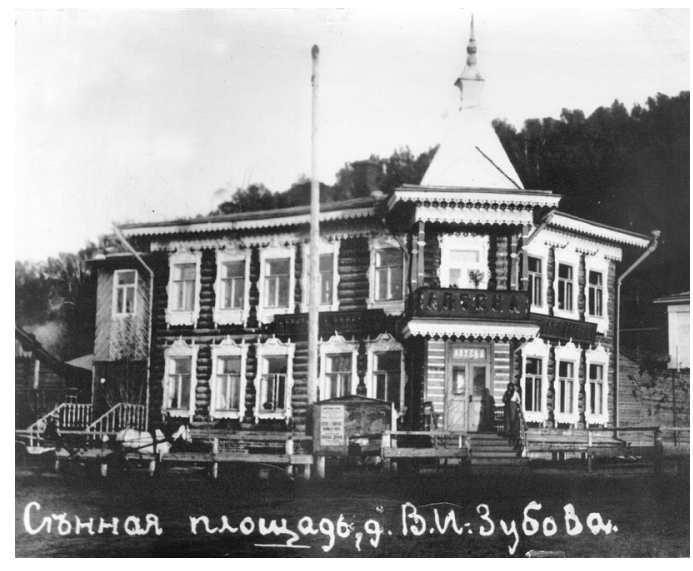

Илл. 3. Дом купца В. И. Зубова. Сенная площадь / ул. Бол. Олонская, $39^{19}$

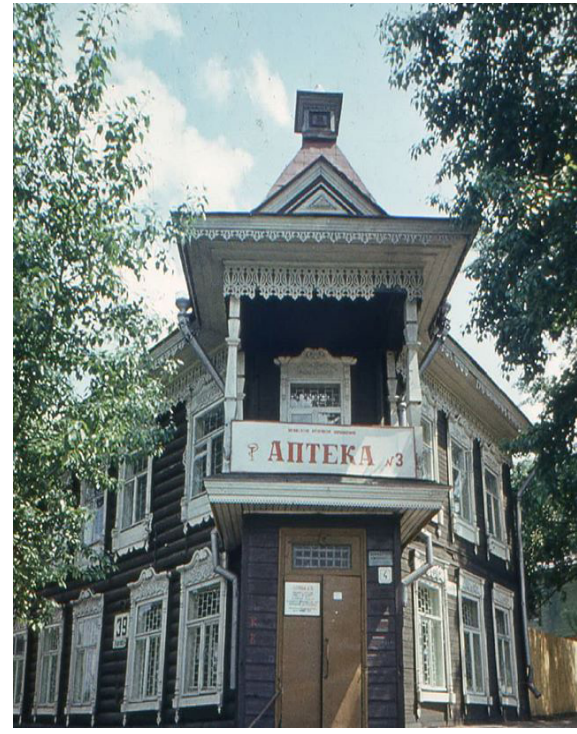

Илл. 4. Дом купца В. И. Зубова на ул. Бол. Олонская, 39. Аптека № 3. ГААК. Фотодокументы. Оп. 1. Д. 479)

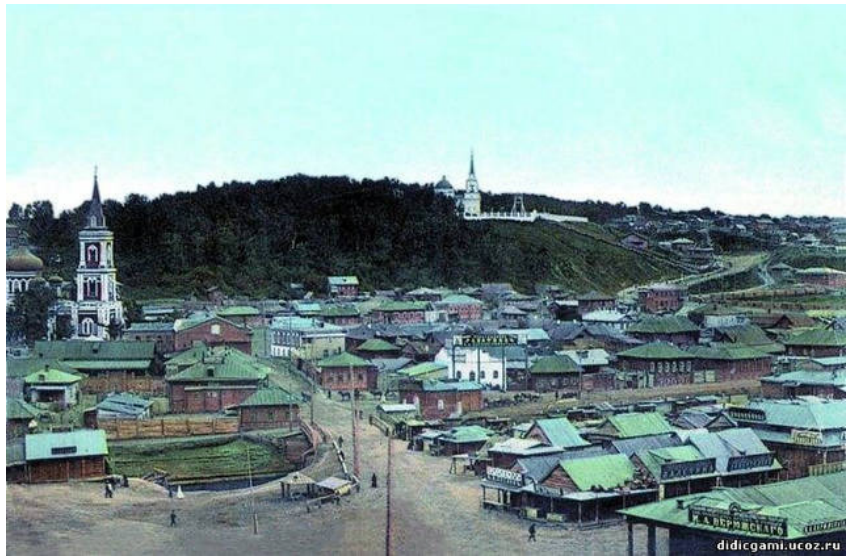

Илл. 5. Барнаул (литография). Фото С. И. Борисова
Ф. М. Достоевский жил у подножия «барнаульского Олимпа», как его называли местные жители. На вершине находилось Нагорное кладбище, открывался изумительный вид на реку Обь и весь город. 


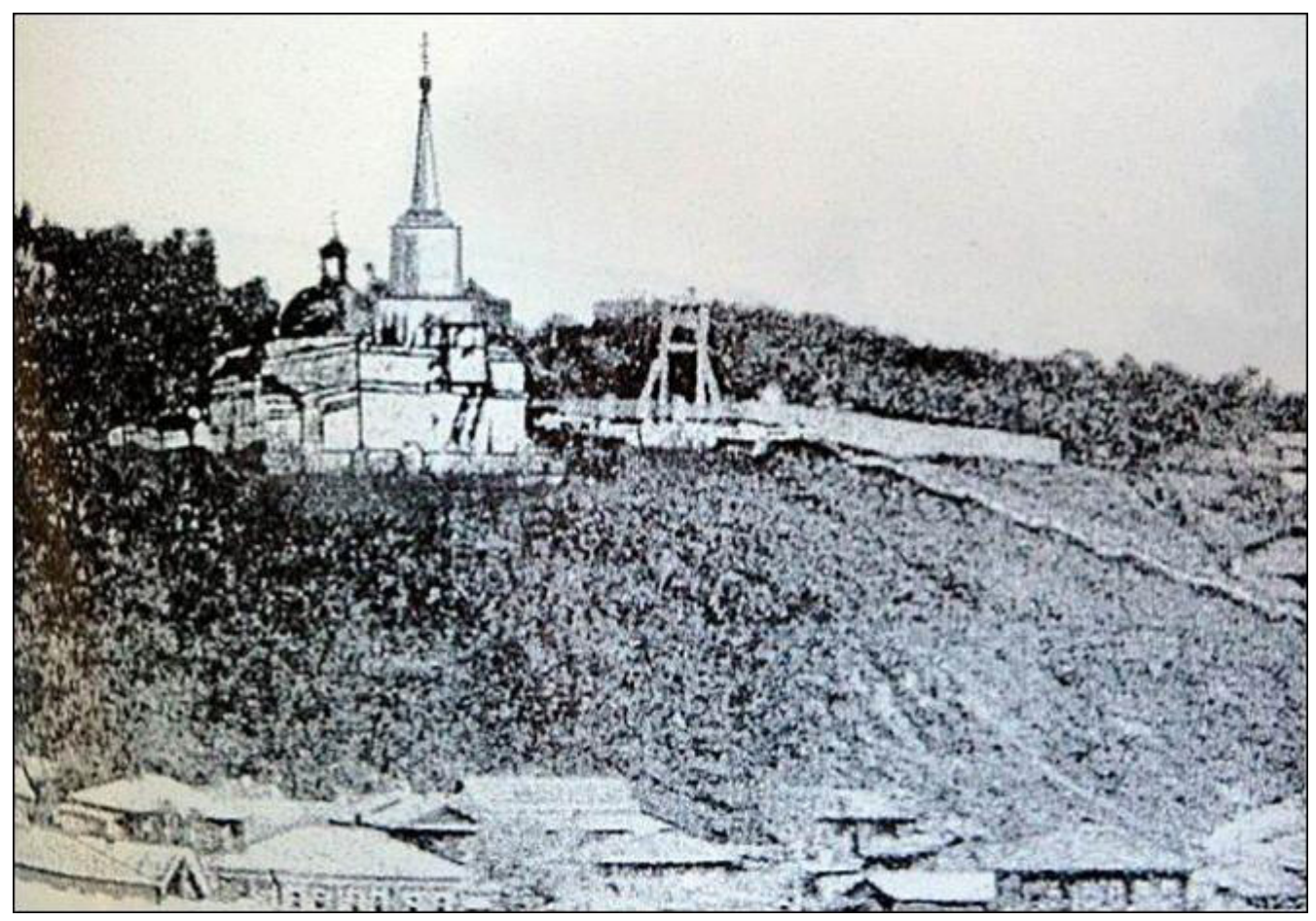

Илл. 6. Иоанно-Предтеченский храм на Барнаульской горе [Гармс, 2011b: 74]

Возможно, во время совместных прогулок П. П. Семенов, хорошо знакомый с коллекциями В. Ф. Геблера в краеведческом музее и его трудами как энтомолога, биолога и географа, рассказал другу трогательную историю любви немецкого доктора, женившегося в Барнауле на русской и прожившего здесь в любви и согласии в браке 40 лет. «21 марта 1850 г. $Ф$. В. Геблер умер в Барнауле. Его жена, Александра Степановна Геблер (урожденная Зубарева), с которой он счастливо прожил много лет, ушла вслед за ним на следующий же день. Об этом редком событии еще долго помнили в Барнауле. Они были погребены вместе на Нагорном кладбище, носившем в народе название “Барнаульского Олимпа”. Над могилой был поставлен кирпичный фундамент с чугунной доской “Доктор Федор Вильгельмович Геблер”» [Гармс, 2011b: 72]. 


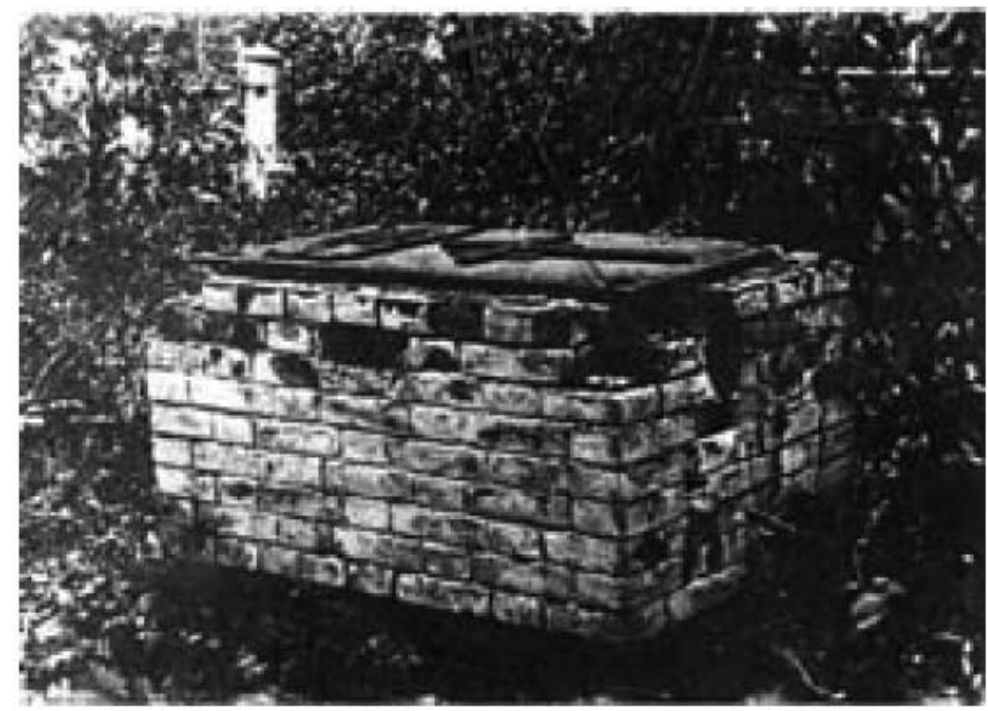

Илл. 7. Могила доктора Геблера на Нагорном кладбище в Барнауле. Фотоснимок с негатива П. А. Казанского. Нач. ХХ в. (Алтайский государственный краеведческий музей, ОФ 498)

В настоящее время в Нагорном парке г. Барнаула установлен памятный знак Ф. В. Геблеру.

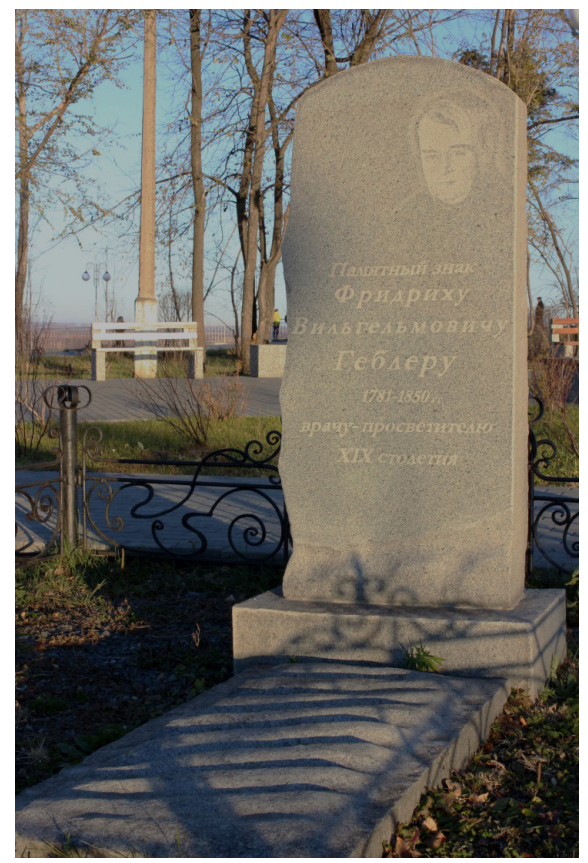

Илл. 8. Фото: И. Шестухина 
История барнаульских Петра и Февронии, завершившаяся за шесть лет до посещения города П. П. Семеновым и Ф. М. Достоевским, бытовала в Барнауле как предание о чудесной любви ${ }^{20}$. Она была важна для обоих: писатель, пережив любовные страдания, наконец стал женихом, а ученый-биолог и географ был неутешным вдовцом, в 1853 г. потерявшим любимую жену Веру Александровну (урожденную Чулкову) и потому решившимся на опасное путешествие в горы Тянь-Шань к агрессивно настроенным туземцам.

Могила Ф. В. Геблера и его жены была расположена в красивом месте, в непосредственной близости от места жительства П. П. Семенова: «...правый берег реки поднимался высоко и довольно живописно над её [реки] запрудой; на нем строилась кладбищенская церковь» ${ }^{21}$. Поскольку оба друга любили прогулки, то, возможно, они могли посетить могилу «народного доктора» и его жены, освященную городской молвой.

Трое ученых-энциклопедистов: А. фон Гумбольдт, Ф. В. Геблер и П. П. Семенов, приезжавшие с научными целями в Барнаул, могли послужить прототипами образа ученого-энтомолога из Германии. Необходимо учитывать, что любой сатирический образ создается путем обобщения, всегда имеет полигенетическую природу, отсылая не к одному, а сразу к нескольким прототипам. В процессе творческого обобщения происходит ироническая деформация прототипа(-ов), но, тем не менее, даже пародийное сходство оставляет возможность разгадывания с большой степенью достоверности. Поэтому логично допустить, что в сатирическом образе безымянного немецкого ученого могли отразиться черты и других исследователей Алтая, хотя, более вероятно, что доминантой образа биолога стал Ф. В. Геблер. Он единственный отвечает всем признакам образа: немецкое происхождение, родоначальник систематической энтомологии на Алтае, предпринимал специальные поездки в столицы для публикации научных трудов, вел обширную переписку ${ }^{22}$, издал две работы о насекомых: «Insecta Sibiriae rariora, descripsit» (= «Редкие насекомые Сибири, описание») и «Замечания о насекомых Сибири, в особенности Алтая».

Из беседы с П. П. Семеновым или из самой работы Ф. В. Геблера «Insecta Sibiriae rariora, descripsit» Ф. М. Достоевский мог узнать о насекомых, обитающих в Сибири (в статье описано 10 видов). В конце исследования даны примечания и изображение насекомых, вероятно, выполненные самим автором. Особенно важным для Достоевского представляется насекомое под названием Leptura altaica.

Описание насекомого № 8 Leptura altaica на латинском языке расположено на с. 331-332.

Перевод: 


\section{«8. Leptura altaica.}

Грудь обратноконическая, надкрылья утонченные, черные; середина груди, надкрылья, сегменты брюшка и конечности красные.

\section{Описание.}

Облик и размеры как у Leptura thoracicae.

Голова с отчетливой шейкой, большая, широкая, яйцевидная, в середине желобчатая, черная, покрытая точками, слегка блестящзя, серо-опушённая; глаза серо-голубые. Усики удлиненные, первые два членика с черным основанием, на верхуике красные; третий и четвертый полностью красные; пятый в основании красный, на верхушке черный; последний черный.

Грудь обратноконическая, по бокам не растиренная, центральная линия гладкая, точечная, красная, серо-опушенная; по краю спереди и сзади слегка загнутая, черная.

Заднеспинка треугольная, острая, черная.

Надкрылья шире груди и почти в четыре раза длиннее, с выљающимися вперёд плечами ${ }^{23}$, слегка сужающиеся к выемчатой верхушке, мелко-точечные, красные, слегка блестящие, желто-опушённые. Крылья в основании красноватые.

Всё тело с нижней стороны желто-опушённое; голова, грудь и брюшко с черным основанием, сегменты красные. Ноги (конечности) беговые, красные, задние удлиненнье.

Обитает около Барнаула, очень редкий» ${ }^{24}$.

В работе дается описание взрослой особи жука Leptura altaica. В современной систематике это насекомое относится к классу Insecta $\rightarrow$ подклассу Pterygota $\rightarrow$ инфраклассу Neoptera $\rightarrow$ надотряду Holometabola $\rightarrow$ отряду Coleoptera $\rightarrow$ подотряду Polyphaga $\rightarrow$ инфраотряду Cucujiformia $\rightarrow$ надсемейству Chrysomeloidea $\rightarrow$ семейству Cerambycidae $\rightarrow$ подсемейству Lepturinae $\rightarrow$ трибе Lepturini $\rightarrow$ роду Macroleptura $\rightarrow$ виду Macroleptura thoracica ${ }^{25}$.

Синонимами и родовыми комбинациями описанного барнаульским ученым насекомого Leptura altaica Gebler, 1817 (= Leptura altalca Gebler, 1830 [sic]) являются Leptura thoracica Creuzer, 1799 (Illiger, 1805; Bense, 1995) = Strangalia thoracica Mulsant, 1863 = Leptura (Stenura) thoracica Ganglbauer, 1882 (Bates, 1884) = Leptura (Strangalia) thoracica Heyden, 1893 = Leptura (Strangalia) thoracica var. obscurissima Pic, $1900=$ Strangalia (Strangalia) thoracica Aurivillius, 1912 [catalogue] = Leptura (Leptura) thoracica Gressitt, 1951 = Macroleptura thoracica Nakane \& Ohbayashi, 1957 (Sama, 2002; Wang, 2003; Sláma, 2006; Ohbayashi \& Niisato, 2007; Sama et al., 2008) = Leptura (Megaleptura) thoracica Kusama, 1973 = Megaleptura thoracica Hayashi, 1980²6. 


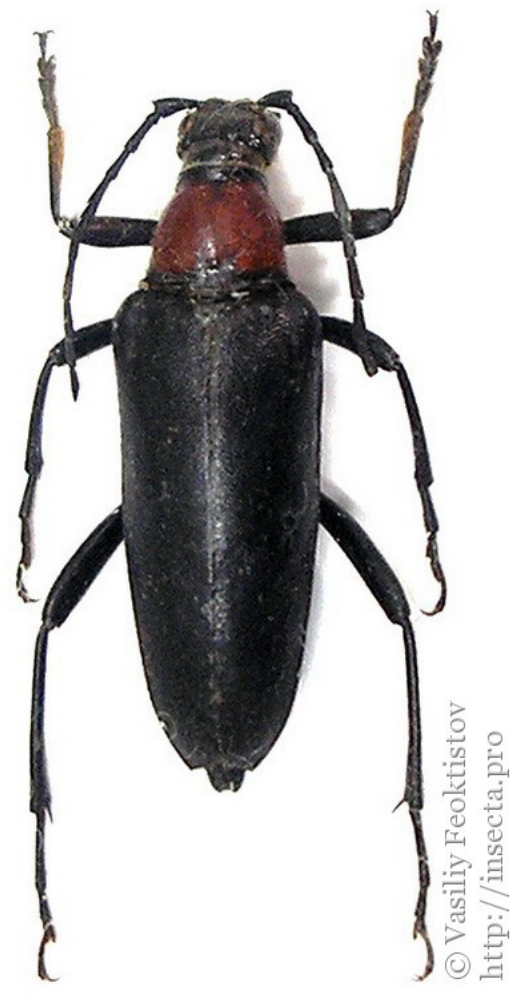

Илл. 9. Macroleptura thoracica

$\left(\right.$ Creutzer, 1799) ${ }^{27}$

Современный сибирский энтомолог В. Г. Шиленков отмечает большой вклад Геблера в науку: «Барнаульский врач Ф. А. Геблер интенсивно изучал жуков южной Сибири и северо-восточного Казахстана» [Шиленков: 4]. К сожалению, его обширная энтомологическая коллекция в 1401 экземпляр, подаренная ученым краеведческому музею, ныне утрачена.

Как известно, насекомое в своем развитии с полным превращением проходит четыре стадии: яйцо - личинка - куколка - имаго (бабочка или жук) - в зависимости от принадлежности к отряду ${ }^{28}$. Поэтому червеобразная личинка для не посвященного в тайны энтомологии вполне похожа на необычного «червячка с рожками».

Скорее всего, Ф. М. Достоевский неглубоко вникал в подробности научной систематики насекомых и специфики энтомофауны Сибири, - сам объект научного изучения казался забавным, и писателю важно было обыграть ситуацию его изучения как анекдотическую («Один немецкий ученый, нарочно приезжавший из Карльсруэ исследовать особенный род червячка 
с рожками (курсив мой. - E. С.), который водится в нашей губернии, и написавший об этом червячке четыре тома...» - Д30; 2: 297).

Достоевским при упоминании об ученом использовано наречие «нарочно», имеющее в словарях помету «разг.» и употребляющееся в значении «специально». Комический образ создается именно на столкновении серьезного (ученый-энтомолог из Германии) и описания предмета его изучения в игровом варианте. Объект научного изучения биолога назван не традиционно, по-латыни, а с использованием уменьшительно-ласкательного суффикса -ок («особенный род ${ }^{29}$ червячка с рожками»), с целью усиления игрового и юмористического характера образа ученого.

Достоевский пишет не научный труд, где важна родо-видовая систематика и точность, а комическое художественное произведение, следовательно, объект изображения значительно снижается, подвергается комическому обыгрыванию. «Особенный род червячка с рожками» может быть расценен не только как метафора, но и как аллегория или даже гротеск, понятный только узкому кругу посвященных (А. Е. Врангель, П. П. Семенов, В. П. Демчинский).

Во-первых, Достоевский, упоминая в повести «особенный род червячка с рожками», стремился подчеркнуть провинциальность и намекнуть на склонность к сплетням как отличительную черту жителей Мордасова, ярко демонстрируя уровень их духовных интересов. Поневоле вспоминается характеристика Барнаула, данная Ф. М. Достоевским в письме А. Е. Врангелю от 21 декабря 1856 г.: «...Хлопотливый (курсив мой. - E. С.) город, и сколько в нем сплетен и доморощенных Талейранов!» (Д30; 28, 252).

Во-вторых, отмеченный в повести «особенный род червячка с рожками», вне зависимости от того, какой вид имел в виду писатель (подгрызающие совки или Leptura altaica), относится к вредителям. Leptura altaica питается березовой корой, подгрызающие совки относятся к полифагам (гp. poly много, phagos - пожирающий), то есть всеядным. У слова полифаг есть и переносное значение: обжора ${ }^{30}$.

Это значение в переносном смысле отражено в словах героини повести Марьи Александровны, так охарактеризовавшей князю К. местное общество:

«...Вы совершенно не знаете здешнего общества, совершенно не знаете! Ведь это только одна выставка своих небывалых достоинств, своих благородных чувств, одна комедия, одна наружная золотая кора. Приподымите эту кору, и вы увидите иелый ад под цветами, целое осиное гнездо, где вас съедят и косточек не оставят! (курсив мой. - Е. С.)» (Д30; 2: 341).

Здесь автор акцентирует главные характеристики жителей Мордасова: склонность к сплетням, лицемерие, тщеславие ${ }^{31}$. 
Резюмируя, отметим, что в повести «Дядюшкин сон» Достоевский иронично обыграл образ немецкого ученого-чудака, который специально приехал в Сибирь с научной целью. Писатель избирает объектом пародии энтомолога, который написал работу об «особенном роде червячка с рожками» ${ }^{32}$. В процессе анализа выяснилось, что сатирический образ имеет полигенетическую природу: прототипами ученого можно назвать Ф. Геблера, А. фон Гумбольдта и П. П. Семенова, которые оставили значительный след в зоологии и посещали Барнаул. Прообразом необычного насекомого могла стать личинка Leptura altaica - очень редкого жука семейства усачей или дровосеков, который обитал в окрестностях города. С личностью Геблера связана и история о подгрызающих совках, гусеница которой могла напоминать «червячка с рожками». Использование писателем эвфемизма названия насекомого подчеркивает отличительные черты обитателей Мордасова: провинциальность и склонность к сплетням, - ярко демонстрируя уровень духовных интересов «жуков-усачей», которых интересует по преимуществу «золотая кора» (намек на добычу золота в Колывано-Воскресенских заводах), а также указывает на паразитарный характер существования чиновников и процветающее взяточничество. Ф. М. Достоевский легко и иронично обыгрывает факты и городские предания, однозначно отсылающие к Барнаулу. Так глубокий анализ гротескного образа ученого из Германии не только отсылает к описанию энтомофауны Сибири и истории Алтая, но и приоткрывает занавес творческой лаборатории писателя, показывая путь от частного образа к аналогиям, параллелям и философским обобщениям.

\section{ПРИМЕЧАНИЯ}

* Выражаю благодарность д-ру биол. наук, проф. Томского государственного университета Александру Леоновичу Эбелю, канд. биол. наук, с.-н. с. Тигирекского государственного заповедника Олегу Яковлевичу Гармсу, д-ру с.-х. наук, проф. кафедры ботаники биологического факультета Алтайского государственного университета Григорию Яковлевичу Стецову, канд. биол. наук, доценту кафедры экологии, биохимии, биотехнологии биологического факультета АлтГУ Павлу Сергеевичу Нефедьеву, канд. биол. наук, доц. кафедры ботаники биологического факультета АлтГУ Алексею Владимировичу Ваганову, канд. биол. наук, доц. кафедры ботаники биологического факультета АлтГУ Полине Дмитриевне Гудковой.

1 См.: [Семыкина], [Кибальник], [Тихомиров], [Старыгина].

2 Достоевский Ф. М. Полн. собр. соч.: в 30 т. Л.: Наука, 1972. Т. 2. С. 297. Далее ссылки на это издание приводятся в тексте статьи с использованием сокращения Д30 и указанием тома, книги (нижний индекс), страницы в круглых скобках.

3 Кроме ученых, Алтай посещали и другие иностранцы в поисках «русской Аляски». Так, например, в надежде быстрого обогащения из Англии в 1848-1853 гг. приезжал архитектор и художник Томас Аткинсон (1799-1861). Подробнее о нем см.: Аткинсон Т., Аткинсон Л. Англичане в Сибири. Приключения и анекдоты / сост. Н. Волкова. М.: Директ-Медиа, 2012. 127 с.; Аткинсон Т. У. Восточная и Западная Сибирь: повествование 
о семи годах исследований и приключений в Сибири, Монголии, степях Киргизии, Китайской Тартарии и части Центральной Азии. СПб.: Альфарет, 2009. 656 с.; Аткинсон Л. Воспоминания о Татарских степях: письма из Барнаула. 1848-1853 гг. Барнаул: Алтайский дом литераторов, 2013; Проскурин В. Н. Путешествие в край Семи Рек // Вестник Библиотечной Ассамблеи Евразии. 2013. № 1. С. 39-41; Проскурин В. Н. Томас Аткинсон в Казахстане // Простор. 2014. № 1. Январь. С. 179-184; Персональный сайт Владимира Проскурина [Электронный ресурс]. URL: http://proskurin.ucoz.kz/publ/ puteshestvie_atkinsona_k_celebnym_vodopadam/5-1-0-227.

4 См.: ГААК. Ф. 2. Оп. 2. Д. 6851. Л. 192-194.

5 Григорий Яковлевич Стецов - доктор сельскохозяйственных наук, профессор кафедры ботаники биологического факультета Алтайского государственного университета.

6 Ткаленко А. Подгрызающие совки: меры борьбы и профилактики // Полезный интернет-журнал «Good-Tips.Pro» [Электронный pecypc]. URL: //https://good-tips.pro/index. $\mathrm{php} /$ house-and-garden/orchard-and-garden/vegetables/cutworms-measures-for-control-andprevention.

7 Источник: www.lepiforum.de

8 О биографии Ф. В. Геблера см. также: [Гармс, 2011a], [Гармс, 2011b], [Тишкина], [Фридрих Вильгельмович Геблер].

9 В России имя ученого произносилось и записывалось на русский манер: Фридрих Август - Федор Вильмов (Вильмотович), Федор Вильгеймович и даже Федор Васильевич. Именно в такой интересной огласовке имя встречается в архивных документах, датированных февралем 1832 г., адресованных инспектору медицинской и фармацевтической частей в Колывано-Воскресенских заводах господину статскому советнику и кавалеру Федору Вильмотовичу Геблеру (ГААК. Ф. 2. Оп. 2. Д. 5795; Оп. 1. Ед. хр. 36). Формулярные списки доктора медицины и хирургии Ф. В. Геблера содержатся в следующих документах ГААК: Ф. 2. Оп. 1. Д. 4027а. Л. 679-687 (ФС 1849 г.); Д. 5377 (нумерация сбита) (ФС 1848 г.); Д. 5367. Л. 42-49.

11 В 1817-1818 гг. ученый специально предпринимает поездки в Санкт-Петербург с целью издания трудов по энтомологии, личного знакомства с крупнейшими российскими учеными в этой области. В 1817 г. в записках Московского общества испытателей природы («Memoires de la Societe Imperiale des Naturalistes de Moscou») был опубликован первый результат его научных трудов «Insecta Sibiriae rariorum» - работа о редких сибирских насекомых. См.: Gebler Fridericus [= Геблер Ф. В.] Insecta Sibiriae rariora, descripsit [= Редкие насекомые Сибири, описание] // Memoires de la Societe [Imperiale] Naturalistes de Moscou. Moscou, 1817. C. 315-333 + Tab. XIV, F. 4, 5. Опис. табл.: с. 464-465. URL: http:// books.e-heritage.ru/book/10086117.

Обобщающий характер имеет исследование «Замечания о насекомых Сибири, в особенности Алтая» (см.: Gebler F. W. Observations entomologicae // Memoires de la Socicte lmperiale des Naturalistes de Moscou. 1823. T. VI).

12 См.: ГААК. Ф. 2. Оп. 1. Д. 5377, 4027а.

13 Большая часть его обширного научного наследия, 34 тома - книги in folio (лат. в целый лист, т. е. самый большой формат книги), в которых рисунки раскрашивались вручную в каждом экземпляре. См. об А. фон Гумбольдте подробнее: Alexander von Humboldt [Электронный ресурс] // Dieter Wunderlich. URL: https://dieterwunderlich.de/ Alexander_Humboldt.htm.

14 Поездка осуществлялась за счет российской казны и имела целью сбор и всестороннюю оценку состояния Колывано-Воскресенских заводов в связи с их передачей в ведомство 
Министерства финансов.

15 В России А. фон Гумбольдт накопил множество наблюдений в области геологии, географии и биологии. В научных трудах по Центральной Азии он опирался на исследования Геблера как авторитетного специалиста в области минералогии, геологии и истории формирования земной коры.

16 В 19 лет, будучи студентом, Ф. Геблер был избран членом знаменитого «Йенского общества минералогии», президентом которого был И. В. Гете, который в это же время читал лекции в Йенском университете [Гармс, 2011b: 12]. Позднее барнаульский врач и ученый передал И. В. Гете обширную коллекцию алтайских минералов.

17 Само путешествие в Тянь-Шань П. П. Семенов задумал в 1854 г. как апробацию теоретической идеи А. фон Гумбольдта о вулканическом происхождении этих гор. В силу возраста немецкий ученый уже не мог проверить свою гипотезу, которую удалось опровергнуть его русскому ученику.

18 Семенов Тянь-Шаньский П. П. Путешествие в Тянь-Шань. М.: Юрайт, 2018. С. 97.

19 Источник фото: портал «История Барнаула» (//https://vaul.ru/barnaul/istoriya-barnaula).

20 Несколько снижают представление о чете Геблер последние архивные разыскания д. и. н., проф. АлтГУ В. А. Должикова (см.: [Должиков: 43-45]).

21 Семенов Тянь-Шаньский П. П. Путешествие в Тянь-Шань. С. 16.

22 Ф. В. Геблер вел переписку с университетским профессором Ю. К. Лодером, доктором И. Я. Геннингом, К. Г. Маннергеймом, О. Е. Коцебу, П. Дежаном, с директором зоологического музея Академии наук в Петербурге академиком И. Ф. Брандтом, с профессором Московского университета Ф. фон Вальдгеймом, с берлинским зоологом Б. Клюге, цюрихском академиком доктором О. Геером, И. И. Эшшольцем, с ботаниками К. Ледебуром и с его спутниками А. А. Бунге и К. Майером [Гармс, 2011b: 48, 79].

23 Не совсем понятно, что за деталь строения (прим. переводчика А. Л. Эбеля, д-ра. биол. наук, профессора Томского государственного университета).

24 Перевод с латинского - д-ра биол. наук, проф. Томского гос. ун-та Александра Леоновича Эбеля. В оригинале:

«8. Leptura altaica. Thorace obconico, elytris attenuatis nigra, thorace medio, elytris, abdominis segmentis pedibusque rubris.

Descriptio.

Habitus et magnitudo L. thoracicae.

Caput collo distincto, magnum, latum, ovale, medio canaliculatum, nigrum, punctatum, subnitidum, cinereo-pubescens; oculi glauci. Antennae elongatae, articulis duobus primis basi nigris, apice rubris, tertio et quarto totis rubris, quinto basi rubro, apice nigro, ultimis nigris.

Thorax obconicus, lateribus non dilatatus, linea media laevi, punctatus, ruber, cinereo pubescens, margine antico et postico subreflexis, nigris.

Scutellum triangulare, acutum, nigrum.

Elytra thorace latiora et fere quadruplo longiora, humero prominulo, ad apicem versus sensim attenuata, apice emarginata, tenuiter punctata, rubra, subnitida, fuivo-pubescentia. Alae basi rubescentes.

Subtus totum corpus tenuiter fulvo - pubescens, capite pectore abdominisque basi nigris, segmentis rabris. Pedes cursorii, rubri, postici elongati.

Habitat circa Barnaul rarissima».

25 Портал «Naturaliste.ru» (http://insecta.pro/ru/taxonomy/173121).

26 См. портал «Naturaliste.ru» (http://insecta.pro/ru/taxonomy/173121). 


$$
\lim _{(\rightarrow)}
$$
(гp. phagein - есть) - «чрезмерное потребление пищи, обусловленное усиленными процессами усвоения питательных веществ (напр., в период роста организма или выздоровления после острых инфекционных заболеваний); иногда признак нек-рых болезней...» (Словарь иностранных слов. М., 1990. С. 399).

31 Ср. разговорное выражение заморить червячка - «перекусить на голодуху» (Даль В. И. Толковый словарь живого великорусского языка. СПб.; М.: Тип. М. О. Вольфа, 1882. T. 4. С. 607).

32 К сожалению, не сохранились ни рукописи первоначального комического романа, ни черновики повести «Дядюшкин сон». А ведь они могли бы содержать рисунки (как это зачастую бывает в других рукописях писателя), которые сделали бы нашу гипотезу более аргументированной. По наблюдению К. А. Баршта, «идеографические знаки в рукописях писателя - такая же неотъемлемая и существенная часть его творческих записей, как и вербальные тексты» [Баршт: 78]. Рисунки имели автокоммуникативный характер, были катализатором творческого процесса Достоевского.

\section{СПИСОК ЛИТЕРАТУРЫ}

1. Александр фон Гумбольдт в Сибири // Экспедиционный центр Красноярского краевого отделения русского географического общества [Электронный ресурc]. - URL: http://ec-rgo-sfo.com/lichnosti/304-aleksandr-fon-gumbolt-v-sibiri (20.04.2019).

2. Баршт К. А. Об атрибуции портретных рисунков Достоевского // Неизвестный Достоевский. — 2015. — № 2. - С. 77-109 [Электронный ресурс]. — URL: http://unknowndostoevsky.ru/files/redaktor_pdf/1447754821.pdf (20.04.2019). DOI: 10.15393/j10.art.2015.2467

3. Гармс О. Я. 230 лет со дня рождения исследователя Ф. В. Геблера (1781-1850) // Алтайский край. Календарь знаменательных и памятных дат. - 2011. - С. 116-119. (a)

4. Гармс О. Я. Доктор Геблер - исследователь Алтая: к 230-летию со дня рождения. Барнаул: Алтайский дом печати, 2011. - 113 c. (b)

5. Должиков В. А. Институциональные истоки коррупции в «Кабинетском» хозяйстве Алтайского горного округа (1830-е - начало 1860-х гг.) // Хозяйственное и культурное развитие Урала и Сибири в XIX-XXI вв. - Томск: Изд-во Том. гос. архит.-строит. унта, 2012. - Вып. 4. - С. 41-46.

6. Кибальник С. А. Проблемы интертекстуальной поэтики Достоевского. - СПб.: Петрополис, 2013. - 363 с.

7. Козлов И. В. Петр Петрович Семенов Тянь-Шанский. - М.: Просвещение, 1983. - 96 с.

8. Сафронова Е. Ю. К вопросу о городе Мордасове: А. Н. Гернгросс и Ф. М. Достоевский (архивные разыскания) // Культура и текст. - 2018. - № 1 (38). - С. 118-143.

9. Семыкина Р. С-И. Специфика комического мира в повести Ф. М. Достоевского «Дядюшкин сон» // Культура и текст: литературоведение: сб. науч. тр. / РГПУ им. А. И. Гер- 
цена, Барнаул. гос. пед. ун-т; [под ред. Г. П. Козубовской]. - СПб.; Барнаул, 1998. Ч. 2. - C. 89-92.

10. Старыгина В. О. «Дядюшкин сон» как комическая повесть // Филологические науки в России и за рубежом: материалы II Международной науч. конф. (г. Санкт-Петербург, ноябрь 2013 г.). - СПб., 2013. - С. 24-26 [Электронный ресурс]. — URL: https://moluch. $\mathrm{ru} / \mathrm{conf} / \mathrm{phil} /$ archive/106/4459/ (20.04.2019).

11.Тихомиров Б. Н. Грустные и смешные персонажи Достоевского // Достоевский Ф. М. Малая проза. Книга первая: Слабое сердце; Чужая жена и муж под кроватью; Маленький герой; Дядюшкин сон / сост., ст. и коммент. Б. Н. Тихомирова. - СПб.: Вита Нова, 2017. - С. 396-449.

12. Тихомиров Б. Н. Комментарии // Достоевский Ф. М. Малая проза. Книга первая: Слабое сердце; Чужая жена и муж под кроватью; Маленький герой; Дядюшкин сон / сост., ст. и коммент. Б. Н. Тихомирова ; илл. А. А. Джигирей. - СПб.: Вита Нова, 2017. C. 329-395.

13. Тишкина Т. В. О необходимости сохранения памяти о Ф. В. Геблере - исследователе Алтая и одном из основателей Барнаульского музея (по материалам деятельности местных краеведческих организаций в 1920-е гг.) // Известия АлтГУ. Исторические науки и археология. - 2018. - № 2 (100). - С. 140-144.

14. Фридрих Вильгельмович Геблер (1781-1850): биобиблиографический указатель / Алт. краев. универс. науч. б-ка им. В. Я. Шишкова; Алт. гос. краевед. музей; сост. Н. В. Воробьева, Е. В. Павлушкина, Л. А. Сметанкина, Э. Г. Штанько; авт. вступ. ст. О. В. Падалкина; отв. ред. В. С. Олейник. - Барнаул: Агентство рекламных технологий, 2008. $-36 \mathrm{c}$.

15. Шиленков В. Г. Жужелицы рода Carabus L. (Coleoptera, Carabidae) Южной Сибири. Иркутск: Изд-во Иркут. ун-та, 1996. - 80 с.

\section{АРХИВНЫЕ ИСТОЧНИКИ}

Государственный архив Алтайского края (ГААК). Ф. 2. Оп. 1. Ед. хр. 36; Д. 4027a, 5377, 5367, 5377, 6433а; Оп. 2. Д. 6851, 5795. 
Elena Yu. Safronova

(Barnaul, Russian Federation)

esafr@mail.ru

\title{
The Prototype of a German Scientist in the Story "Uncle's Dream" of F. M. Dostoevsky
}

\begin{abstract}
The article makes an attempt to identify a prototype of the image of an entomologist in the novel "Uncle's Dream" by F. M. Dostoevsky. According to the author's observations, it was F. V. Gebler, the founder of the systematic entomology in the Altai region, the author of scientific papers on insects "Insecta Sibiriae rariora, descripsit" (= Rare insects of Siberia, description) and the "Notes on the insects of Siberia, especially of the Altai". In addition, the image of the entomologist assumed some features of A. fon Humboldt, who visited Barnaul, and a friend of the writer P. Semyonov, who during the expedition to the Tien Shan in 1856-1857 spent winter in Barnaul (the mining capital of the Altai). Dostoevsky mentions in the novel "a particular species of worm with horns". The writer chooses the object of the researcher's irony a very rare insect Leptura altaica, living in the vicinity of Barnaul, parody plays the facts and urban legends and creates allusions, clearly referring to Barnaul.
\end{abstract}

Keywords: Dostoevsky, “Uncle's Dream”, F. V. Gebler, the image of the scientist, Leptura altaica, siberian text, Barnaul, Alexander von Humboldt, P. P. Semenov-Tyan-Shansky

About the author: Safronova Elena Yu. - PhD of Philology, Senior Lecturer of the Department of General and Applied Philology, Literature and the Russian Language Altay State University (pr. Lenina, 61, Barnaul, 656049, Russian Federation)

Received: April 20, 2019

Date of publication: June 30, 2019

For citation: Safronova E. Yu. The Prototype of a German Scientist in the Story "Uncle's Dream" of F. M. Dostoevsky. In: Neizvestnyy Dostoevskiy [The Unknown Dostoevsky], 2019, no. 2, pp. 110-129. DOI: 10.15393/j10.art.2019.4041 (In Russ.)

\section{REFERENCES}

1. Alexander von Humboldt in Siberia. In: Ekspeditsionnyy tsentr Krasnoyarskogo kraevogo otdeleniya russkogo geograficheskogo obshchestva [Expeditionary Center of the Krasnoyarsk Regional Branch of the Russian Geographical Society]. Available at: http://ec-rgo-sfo.com/ lichnosti/304-aleksandr-fon-gumbolt-v-sibiri (accessed on April 20, 2019). (In Russ.)

2. Barsht K. A. About Attribution of Portrait Drawings of Dostoevsky. In: Neizvestnyy Dostoevskiy [The Unknown Dostoevsky], 2015, no. 2, pp. 77-109. Available at: http://unknown-dostoevsky.ru/files/redaktor_pdf/1447754821.pdf (accessed on April 20, 2019). DOI: 10.15393/ j10.art.2015.2467 (In Russ.)

3. Garms O. Y. 230 Years Since the Birth of the Researcher F. V. Gebler (1781-1850). In: Altayskiy kray. Kalendar' znamenatel'nykh i pamyatnykh dat [Altai Krai. Calendar of Significant and Memorable Dates], 2011, pp. 116-119. (In Russ.) (a)

4. Garms O. Ya. Doktor Gebler - issledovatel' Altaya: $k$ 230-letiyu so dnya rozhdeniya [Dr. Gebler is a Researcher of Altai: to the 230th Anniversary of His Birth]. Barnaul, Altayskiy dom pechati Publ., 2011. 113 p. (In Russ.) (b) 
5. Dolzhikov V. A. The Institutional Origins of Corruption in the "Cabinet" Economy of the Altai Mountain District (1830s - Early 1860s). In: Khozyaystvennoe i kul'turnoe razvitie Urala $i$ Sibiri v XIX-XXI vekakh [Economic and Cultural Development of the Urals and Siberia in the 19th - the 21th Centuries]. Tomsk, The Tomsk State University of Architecture and Building Publ., 2012, issue 4, pp. 41-46. (In Russ.)

6. Kibalnik S. A. Problems of Intertextual Poetics of Dostoevsky. St. Petersburg, Petropolis Publ., 2013. 363 p. (In Russ.)

7. Kozlov I. V. Petr Petrovich Semenov Tyan-Shansky. Moscow, Prosveshchenie Publ., 1983. 96 p. (In Russ.)

8. Safronova E. Yu. To the Problem of the City of Mordasov: A. N. Gerngross and F. M. Dostoevsky (archival search). In: Kul'tura i tekst [Culture and Text], 2018, no. 1 (38), pp. 118-143. (In Russ.)

9. Semykina R. S.-I. The Specifics of the Comic World in the Story of F. M. Dostoevsky's “Uncle's Dream”. In: Kul'tura i tekst: literaturovedeniye: sbornik nauchnykh trudov [Culture and Text: Literary Criticism: a Collection of Scientific Papers]. St. Petersburg, Barnaul, 1998, part 2, pp. 89-92. (In Russ.)

10. Starygina V. O. "Uncle's Dream" as a Comic Story. In: Filologicheskiye nauki v Rossii i za rubezhom: materialy II Mezhdunarodnoy nauchnoy konferensii (g. Sankt-Peterburg, noyabr' 2013 g.). [Philological Sciences in Russia and Abroad: Materials of the II Intern. Scientific Conference (St. Petersburg, November, 2013)]. St. Petersburg, 2013, pp. 24-26. Available at: https://moluch.ru/conf/phil/archive/106/4459/ (accessed on April 20, 2019). (In Russ.)

11. Tikhomirov B. N. Sad and Funny Characters of Dostoevsky. In: Dostoyevsky F. M. Malaya proza. Kniga pervaya: Slaboye serdtse; Chuzhaya zhena i muzh pod krovat'yu; Malen'kiy geroy; Dyadyushkin son [Small Prose of Fedor Dostoevsky. Book One: Weak Heart; A Foreign Wife and Husband Under the Bed; Little Hero; Uncle's Dream]. St. Petersburg, Vita Nova Publ., 2017, pp. 396-449. (In Russ.)

12. Tikhomirov B. N. Comments. In: Dostoyevsky F. M. Malaya proza. Kniga pervaya: Slaboye serdtse; Chuzhaya zhena i muzh pod krovat'yu; Malen'kiy geroy; Dyadyushkin son [Small Prose of Fedor Dostoevsky. Book One: Weak Heart; A Foreign Wife and Husband Under the Bed; Little Hero; Uncle's Dream]. St. Petersburg, Vita Nova Publ., 2017, pp. 329-395. (In Russ.)

13. Tishkina T. V. The Need to Preserve the Memory of F. V. Gebler, a Researcher of Altai and One of the Founders of the Barnaul Museum (Based on the Materials of Local Lore Organizations in the 1920s). In: Izvestiya Altayskogo gosudarstvennogo universiteta. Istoricheskiye nauki i arkheologiya [Izvestiya of Altai State Univarsity. Historical Sciences and Archeology], 2018, no. 2 (100), pp. 140-144. (In Russ.)

14. Friedrich Vilgelmovich Gebler (1781-1850): Biobibliographic Index. Barnaul, Agency for Advertising Technologies Publ., 2008. 36 p. (In Russ.)

15. Shilenkov V. G. Ground Beetles of the Genus Carabus L. (Coleoptera, Carabidae) of Southern Siberia. Irkutsk, Irkutsk Publishing House University Publ., 1996. 80 p. (In Russ.) 